\title{
TAFSIR IBN KATSIR: METODE DAN BENTUK PENAFSIRANNYA
}

\author{
Maliki \\ Universitas Islam Negeri (UIN) Sunan Kalijaga Yogyakarta \\ Email: malicarabia12345@gmail.com
}

\begin{abstract}
Ibn Katsir appeared or entered in the middle ages (8th century H / 15th century AD), But when viewed from the side of his method and form of exegesis. Ibn Kathir is in the "middle" position, meaning from the side of the form he is in the classical position because it uses the form of commentary bil ma'tsür, where as if seen from the side of Ibnu Katsir method is in the mid-century position by using tahlili method, where this method has not been done when the classical era.
\end{abstract}

\begin{abstract}
Abstrak: Ibnu Katsir muncul atau masuk dalam abad pertengahan (abad ke-8 H/abad ke-15 M), akan tetapi jika dilihat dari sisi metode dan bentuk tafsir nya. Ibnu Katsir berada dalam posisi "tengah-tengah", artinya dari sisi bentuk ia berada dalam posisi klasik karena menggunakan bentuk tafsir bil ma'tsür, sedangkan jika dilihat dari sisi metode Ibnu Katsir berada di posisi era pertengahan dengan menggunakan metode tahlili, dimana metode ini belum dilakukan ketika era klasik.
\end{abstract}

Key Word: Metode, Bentuk Penafsiran, Israilyat

\section{A. Pendahuluan}

Berangkat dari asumsi dasar bahwa hasil penafsiran al-Qur'an itu bersifat relatif, dan bahwa al-Qur' an diklaim sebagai sālihun li kulli 
zamān wa makān, maka dari itu, al-Qur'an harus selalu ditafsirkan seiring dan senafas dengan akselarasi perubahan dan perkembangan zaman. Oleh karena itu, sepeninggal Nabi Muhammad selaku penafsir pertama, al-Qur'nsangat terbuka unt uk kemudianbisaditafsirkan ulang sesuai dengan kaidah-kaidah dan metodologi tafsir yang berkembang dan yang telah ditetapkan oleh ulama atau mufassir. Hal ini juga memperkuat bahwa tidak ada penafsiran yang final dan mutlak. ${ }^{1}$

Seperti yang dikemukakn di atas bahwa penafsiran al-Qur'an selalu berkembang sesuai dengan semangat zaman, hal ini tidak lepas dari perkembangan-perkembangan metodologi yang digunakan oleh para mufassir. Oleh karena itu, jika dilakukan periodesasi terkait dengan perkembangan penafsiran al-Qur'an, hal itu sangat terlihat dengan jelas adanya shifting methodology dikalangan para mufassir, mulai dari masa klasik, tengah, modern sampai kontemporer. Adanya peregerseran tersebut dikarenakan pada kecenderungan sudut pandang dari para mufassir dan latar belakang keilmuan dan juga yang sangat berepengaruh adalah kondisi sosio historis. Namun, dalam tulisan ini, tidak akan membahas terkait dengan perkembangan atau periodesasi penafsiran al-Qur'an tersebut, melainkan akan focus pada metodologi penafsiran pada masa pertengahan dengan melihat kerangka metodologi Tafsir Ibn Kats $\square$ r.

\section{B. Biografi Ibn Kats $\square \mathbf{r}^{2}$}

Ibn Kats $\square \mathrm{r}$ yang menjadi objek dalam pembahasan ini, ulama yang juga biasa di kenal dengan nama Abu al-Fida' ini lahir di Basrah

1 Terakiat argument bahwa tidak ada penafsiran yang final dan mutlak, juga merupakan pandangan dari pakar hermeneutika Barat, Martin Heidegger adalah seorang filosof Jerman (1889-1976) dan Hans Georg Gadamer (1900-2002), lihat, M. Quraish Shihab, Kaidah Tafsir "Syarat, ketentuan, dan Aturan yang Patut anda ketahui dalam memahami ayat-ayat al-Qur'an. (Ciputat: Lentera Hati, 2013), 416422.

${ }^{2}$ Perlu diperjelas bahwa, dalam bidang keilmuan al-Qur'an dikenal dua tokoh dengan nama Ibnu Katsir. Pertama, Ibnu Katsir dengan nama lengkap Abu Muhammad Abdullah bin Katsir Ad-Dary al-Makky yang lahir di Mekkah pada tahun 45 H/665 M. ia adalah seorang ulama dari generasi tabi' in yang dikenal sevagai salah seoarng imam Tujuh dalam Qira'at Sab'ah. Sedangkan Ibnu Katsir yang akan dibahas dalam tulisan ini adalah tokoh mufasisir yang hidup pada awal abd ke-8 $\mathrm{H}$. Lihat, Rosihon Anwar, Melacak Unsur-unsur Israiliyat dalam Tafsir Ath-Thobari dan Tafsir Ibnu Katsir, (Bandung: Pustaka Setia, 1999), 69. 
desa Mijdal pada tahun 700 H/1300 M. Nama lengkapnya adalah Imam ad-DDn Abu al-Fida' Ismail bin al-Khatib Syihab ad-Din Abi Hafsah Umar bin Katsir al-Quraisy Asy-Syafi'i. Dalam literature-literatur yang lain juga disebutkan nama Ibn Katsir dengan gelar al-Bushrawi dibelakang namanya, hal ini berkaitan dengan tempat ia lahir yaitu di Basrah, begitu pula dengan gelar al-Dimasyqi, hal ini dikarenakan kota Basrah adaalah bahagian dari kawasan Damaskus. ${ }^{3}$ Maka dari itu sering juga disebutkan dengan nama Imad al-Din Ismail bin Umar Ibn Katsir al-Quraysi al-Dimasyqi. ${ }^{4}$

Sejak umur tujuh tahun (ada juga pendapat yang menyebut tiga tahun) Ibnu Katsir sudah ditinggal oleh ayahnya yang meninggal dunia. Sejak saat itu, ia diasuh oleh kakaknya (Kamal al-Din Abd Wahhab) di Damaskus. Dari sinilah Ibnu Katsir memulai pengembaraan keilmuannya dengan banyak bertemu dengan para ulama-ulama besar pada saat itu, termasuk Syaikh al-Islam Ibnu Taimiyah, dan juga Baha al-DDn al-Qasimy bin Asakir (w. 723), Ishaq bin Yahya al-Amidi (w. 728). ${ }^{5}$ Ibnu Kats $\square r$ juga banyak mendalami ilmu-ilmu keislaman lainnya, selain dalam bidang tafsir Ibnu Katsir juga sangat menguasai bidang hadis, ${ }^{6}$ fiqih, dan sejarah. Hal itu dibuktikan dengan banyak karya-karyanya yang berkaitan dengan hal tersebut. Maka dari itu, sangat wajar jika dia diberi gelar sebagai mufassir, muhaddits, faqīh, dan muarrikh.

Karir intelektual Ibn Kats $\square$ r mulai menanjak setelah ia banyak menduduki jabatan-jabatan penting sesuai dengan keahlian yang dimilikinya. Misalnya dalam bidang hadis, pada tahun $748 \mathrm{H} / 1348$ M, Ibn Kats $\square$ r menggantikan gurunya Muhammad Ibn Muhammad al-Zahabi (1284-1348 M) di Turba Umm Salih (lembaga Pendidikan), dan pada tahun 756 H/1355 M diangkat menjadi kepala Dar al-Hadis

${ }^{3}$ Rosihon Anwar, Melacak Unsur-unsur Israiliyat.,. , 69.

${ }^{4}$ Dedi Nurhaedi dkk, Studi Kitab Tafsir, hlm. 132

${ }^{5}$ Rosihon Anwar, Melacak Unsur-unsur Israiliyat.,. 70.

${ }^{6}$ Dalam bidang hadis, Ibnu KatsDr banyak belajar dari ulama-ulama Hijaz. Ia memperoleh Ijazah dari al-Wani. Dan banyak belajar dari Jamaluddin alMizzi (w. 724 H/1342 M) penulis kitab Tahdzīb al-kamāl fì asma' al-Rijāl, yang kemudian menjadi mertuanya sendiri. Lihat, Dedi Nurhaedi dkk, Studi Kitab Tafsir, (Yogyakarta: Teras, 2004), hlm. 132. Lihat juga, Saiful Amin Ghofur, Mozaik Mufassir al-Qur'an (dari Klasik Hingga Kontemporer), (Yogyakarta: Kaukaba, 2013), 75. 
al-Asyrafiyah (lembaga pendidikan Hadis) setelah meninggalnya Hakim Taqiyuddin al-Subki (683-756 H/1284-1355 M). kemudian tahun $768 \mathrm{H} / 1366 \mathrm{M}$ diangkat menjadi guru besar oleh Gubernur Mankali Buga di Masjid Umayah Damaskus. ${ }^{7}$ Dan pada akhirnya pada tahun $774 \mathrm{H}$ di usia 74 tahun, Ibn KatsDr meninggal dunia dan dimakamkan disamping Ibnu Taimiyah (gurunya)

Karya-karya yang pernah dihasilkan oleh Ibnu Katsir adalah:

Dalam bidang Sejarah, Ibnu Katsir menulis beberapa kitab antara lain al-Bidāyah wa al-Nihāyah (yang terdiri dari 14 jilid), al-Fusūl fi Sirah al-Rasūl, Thabaqāt asy-Syafi'iyyah, Qasas al-Anbiya, dan Manaqib al-Imām al-Syafi'I. ${ }^{8}$ Dari ketiga buku tersebut, al-Bidāyah wa al-Nihāyah adalah karya monumentalnya dalam bidang sejarah. Kitab ini sampai sekarang masih menjadi kitab rujukan primer dalam kajian sejarah Islam.

Dalam bidang hadis, Ibn KatsDr menulis sejumlah kitab diantaranya Kitab jami al-Masānid wa al-Sunan, al-Kutub al-Sittah, al-Takmīlah fì Ma'rifat al-Siqāt wa al-Du'afā wa al-Mujāhal, alMukhtasar sebagai ringkasan kitab Muqaddimah li 'Ulum al-Hadīs karya Ibn Salah, dan Adillah al-Tanbih li 'Ulum al-Hadīs. ${ }^{9}$ disamping itu, Ibnu Katsir juga mensyarahi kitab Shahih Bukhāri yang penyelesaiannya dilanjut oleh Ibn Hajar al-Asqal[ni. ${ }^{10}$

Dalam bidang fiqih, karyanya tidak terselesaikan. Ia berencana untuk membuat sebuah kitab fiqih yang berlandaskan al-Qur' $\square n$ dan al-hadis, tetapi hanya satu bab yang mengenai ibadah dalam persoalan haji yang ditulis dalam satu bab. ${ }^{11}$

Dalam bidang tafsir ia menulis kitab tafsir 30 juz yang berjudul Tafsìr al-Qur' 'ān al-Adzìm atau yang disebut juga Tafsìr Ibnu Katsìr. ${ }^{12}$ Dan inilah yangh akan penulis bahas dalam pembahasan selanjutnyta,

7 Dedi Nurhaedi dkk, Studi Kitab Tafsir, 133.

${ }^{8}$ Dedi Nurhaedi dkk, Studi Kitab Tafsir., 134.

9 Dedi Nurhaedi dkk, Studi Kitab Tafsir., 134.

${ }^{10}$ Rosihon Anwar, Melacak Unsur-unsur Israiliyat.,. 70.

${ }^{11}$ Rosihon Anwar, Melacak Unsur-unsur Israiliyat.,. 71.

${ }^{12}$ Rosihon Anwar, Melacak Unsur-unsur Israiliyat., 70. 
dengan melihat metode yang digunakan oleh Ibnu Katsir dalam kitab tafsirnya.

Dari karya-karya yang begitu banyak dihasilkan oleh Ibnu Katsir, jadi sangat wajar jika ulama-ulama setelahnya memberikan pujian kepadanya Al-Zahabi misalnya mengatakan "Ibnu katsir adalah imam besar yang bertindak sebagai mufti, ahli hadis, yang agung dan ahli tafsir". Al-Suyuti juga mengatakan "Tafsir Ibnu Katsir merupakan tafsir yang tidak ada duanya. Belum pernah ditemukan kktab tafsir yang sistematika dan karakteristiknya yang menyamai kitab tafsir ini". ${ }^{13}$

\section{Sekilas tentang Tafsir Ibn Katsīr}

Sebelum pemaparan tentang metode penafsiran Ibnu Kats $\square$, terlebih dahulu di jelaskan terkait dengan sejarah/seputar penulisan tafsir Ibnu KatsDr. Pada umumnya para penulis sejarah tafsir menyebut Tafsir Ibn Kats】r dengan nama Tafsīr al-Qur'ān al-Adzìm. Namun, berdasarkan literature-literatur yang ada, tafsir yang ditulis oleh Ibnu Kats $\square r$ ini belum ada kepastian mengenai judulnya. Karena nampaknya Ibn KatsDr tidak pernah menyebut secara khusus nama kitab tafsirnya, seperti yang biasa dilakukan oleh penulis-penulis klasik lainnya yang menulis judul kitabnya pada bagian mukaddimah, akan tetapi, Ali al-Shabuny berpandangan bahwa nama tafsir itu adalah pemberian dari Ibnu Katsir sendiri ${ }^{14}$ Oleh karena itu, ada dua kemungkinan yang bisa terjadi bahwa bisa jadi nama tafsirnya dibuat oleh ulama-ulama setelahnya, yang tentunya judul tersebut bisa menggambarkan tentang isi dari kitab tafsir itu. Dan bisa jadi juga tafsìr al-Qur'ānu al-Adzìm ditulis oleh Ibnu Katsir sendiri (selanjutnya tafsir Ibn Kats $\square$ r). Terlepas dari kesimpangsiuran tersebut, karena tidak adanya bukti secara empiric tentang nama kitab tafsir ini, dan tidak adanya akses untuk bisa meneliti lebih jauh. Yang pastinya ada kitab tafsir yang ditulis sendiri oleh Ibn Kats $\square$ r.

Ketika berbicara tentang geneologi keilmuan, adalah suatu yang niscaya bahwa pemikiran seseorang pasti, sengaja atau tidak

\footnotetext{
${ }^{13}$ Rosihon Anwar, Melacak Unsur-unsur Israiliyat.,. 74.

${ }^{14}$ Rosihon Anwar, Melacak Unsur-unsur Israiliyat.,. 71
} 
disengaja akan dipengaruhi oleh pemikiran-pemikiran sebelumnya. Misalnya, Filsafat Islam sangat dipengaruhi oleh filsafat Yunani yang jauh lebih dulu berekembang. Sedangkan dalam tafsirnya, Ibnu Katsir banyak dipengaruhi oleh ulama-ulama terdahulu Ibn Kats $\square$ r terpenagruh oleh tafsir Ibnu Ahiyyah, tafsir Ibnu Jarir al-Tabari, Ibnu abi Hatim, dan beberapa ulama terdahulu lainnya. ${ }^{15}$ Dan tentunya secara umum pemikirannya banyak dipengaruhi oleh Ibnu Taimiyah selaku gurunya.

Tafsir Ibn KatsDr terdiri dari 8 jilid ${ }^{16}$ (dalam cetakan/terbitan lain disebutkan hanya empat jilid), jilid 1 berisi tafsir surah alFDtihah (1) dan al-Baqarah (2), jilid ke-2 berisi tafsir surah ali ImrDn (3) dan al-Nisa' (4), jilid ke-3 berisi tafsir surah al-MDidah (5) sampai al-A'raf (7), jilid ke-4 berisi tafsir surah al-AnfDl (8) sampai surah al-Nahl (16), jilid ke-5 berisi penjelasan surah al-Isra' (17) sampai alMu'minDn (23), jilid ke 6 berisi tafsir surah al-Nur (24) sampai surah Yasin (36), jilid ke-7 berisi tafsir surah al-ShaffDt (37) sampai surah al-WDqi' ah (56), kemudian jilid ke-8 berisi tafsir surah al-HadDd (57) sampai surah al-N口s (114).

\section{Metode Tafsir Ibn Katsīr}

Dalam meliahat periode munculnya tafsir Ibn Kats $\square$ r, penulis membacanya dengan periodesasi penafsiran yang dibuat oleh Abdul Mustaqim dalam bukunya Dinamika Sejarah Tafsir alQur' '7n. ${ }^{17}$ Yang juga dari periodesasi itu dimungkinkan juga bisa membaca karakteristik penafsiran pada era pertengahan. Berdasarkan periodesasi tersebut maka Tafsir Ibn Kats $\square$ r dapat digolongkan ke dalam tafsir era peretngahan. atau dalam buku lain yang juga ditulis

\footnotetext{
${ }^{15}$ Muhammad Husain Al-Zahabi, Tafsīr wal mufassirūn Juz 1, 175.

${ }^{16}$ Abu al-Fida' Isma'il Ibn Umar Ibn Katsir al-Quraisy al Dimasyqy, Tafsìr al-Qur'ān al-Adzìm, (Dar al-Tayyibah: tt)

${ }^{17}$ Dalam bukunya, Abdul Mustaqim membuat sebuah periodesasi terkait Mazāhib al-Tafsīr dengan ke dalam tiga periode. Pertama periode Klasik (dari abad I-II/6-7 M) di era ini membahas tentang tafsir di era Nabi, era Sahabat dan Tabi'in. kedua, periode pertengahan (dari abad III-IX H/9-15 M). dan ketiga periode Modern -Kontemporer (dari abad XII-XIV H/18-21 M). Lihat, Abdul Mustaqim, Dinamika Sejarah tafsir al-Qur'an "Studi Aliran-aliran Tafsir dari Periode Klasik, Pertengahan Hingga Modern-Kontemporer", (Yogyakarta: Ponpes LSQ kerja sama Adab Press, 2012)
} 
oleh Abdul Mustaqim diistilahkan dengan era afirmatif dengan nalar ideologis. ${ }^{18}$ Karakteristik penafsiran di era tersebut menurut Abdul Mustaqim adalah banyak dipengaruhi atau lebih didominasi oleh kepentingan-kepentingan politik, golongan, mazhab, ideology keilmuan, ${ }^{19}$ karena itulah diistilahkan era afirmatif dengan nalar ideologis. Namun menurut hemat penulis karakteristik tiap periode ini agaknya tidak juga bisa digeneralisasikan bahwa semua tafsir di era peretngahan sarat dengan kepentingan-kepentingan politik atau golongan. Tafsir Ibnu Katsir misalnya ketika menafsirkan ayat tentang antropomorphisme, Ibnu Katsir menafsirkan kalimat “ يَدُ اللَّهِ ، dalam surat al-fath ayat 10 , hal itu tidak sama sebagaiman asy'ariyah menafsirkan kalimat itu, padahal mazhab yang dianut oleh Ibnu Katsir sendiri adalah Ahlusunnah wal Jama'ah. Ibn Kats $\square$ r menafsirkan surat al-fath ayat $10 \mathrm{itu}$, ia mengatakan:

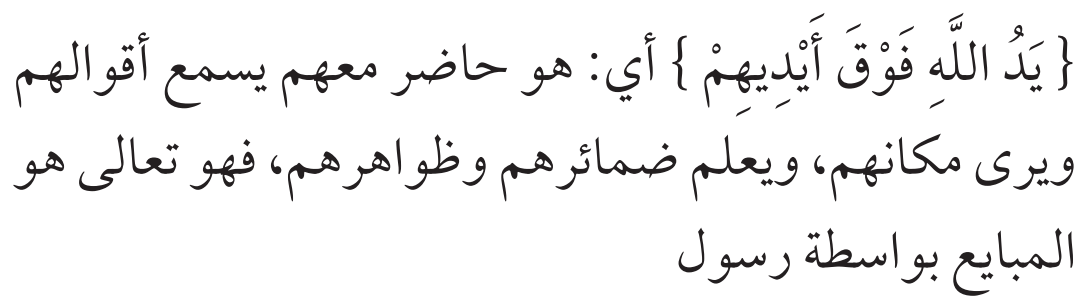

Tuhan berada bersama mereka, Allah mendengarkan perkataan mereka, allah mengetahui yang nampak dan tersembunyi. Dialah Allah sebagi tempat berbaiat dengan perantaraan rasulNya. ${ }^{20}$

Dengan melihat penafsiran tersebut, menurut penulis Ibnu Katsir dalam konteks ini tidak berada pada posisi sebagai asy'ariyah dan juga tidak berada dalam posisi mu'tzailah ${ }^{21}$, Ibnu katsir

${ }^{18}$ Abdul Mustaqim, Epistemologi tafsir Kontemporer, (Yogyakarta: LKIS, 20012), 45.

${ }^{19}$ Abdul Mustaqim, Epistemologi tafsir Kontemporer., 46.

${ }^{20}$ Abu al-Fida' Isma'il Ibn Umar Ibn Katsir al-Quraisy al Dimasyqy, Tafsīr al-Qur'ān al-Adzìm., 329

${ }^{21}$ Prinsip-prinsip yang dipegangi oleh as' ariyah dan Mu'tazilah terkait dengan ayat antropomorphisme itu berbeda. Jika Mu'tzailah menafsirkan kata Yadun adalah kekauasaan, berbeda dengan Asy'ariyah, As'ariyah berpandangan bahwa Tangan tuhan tidak boleh ditafsirkan sebagai kekuasaan, menurutnya tuhan mempunyai mata dan tangan yang tak dapat diberikan gambaran atau defenisi. Lihat, harun Nasution, Teologi Islam (Jakarta: UI Press, 2010), 137-138. 


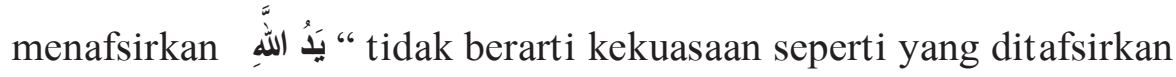
oleh kalangan Mu'tazilah dan juga tidak menafsirkan sebagai tangan tuhan yang tidak bisa digambarkan atau didefenisikan seperti prinsip/ ajaran yang dibawa oleh asy'ariyah. Ibnu katsir mencoba keluar dari kedua pandangan itu dengan mencoba menakwilkan seperti yang telah disebutkan di atas. Oleh karena itu, bahwa tafsir Ibn KatsDr terpengaruh dari kepentingan-kepentingan golongan, hal it u mungkin tidak dalam konteks ini.

Berkaitan dengan kecenderungan/metodologi yang digunakan oleh Ibn Kats $\square r$ dalam tafsirnya, penulis akan menguraikan satu per satu yang berkaitan dengan komponen internal tafsir Ibnu KatsDr yang terdiri dari bentuk tafsir dan metode tafsir dengan menggunakan pemetaan dari Nasharuddin Baidan.

\section{Bentuk tafsir}

Mengenai bentuk tafsir, berdasarkan pemetaan oleh Nasharuddin Baidan bahwa bentuk tafsir ada dua yakni tafsir bil ma 'tsūr (berdasarkan riwayat), dan yang kedua tafsir bil ra'yi (akal). Dengan melihat sejarah penafsiran al-Qur' 'Dn, bentuk tafsir bil ma'tsür bisa dikatakan adalah bentuk yang pertama lahir dalam penafsiran al-Qur' $a n^{22}$, hal ini menurut penulis lebih dikarenakan masa yang tidak terlalu jauh dari Nabi sehingga penafsiran-penafsirannya lebih banyak melihat hadis-hadis Nabi (selaku penafsir pertama al-Qur' 'nn) dan pendapat-pendapat para sahabat dan para tabi'in (dalam ilmu Hadis disebut hadis mauq $\mathrm{f}$ dan maqhtu'). walaupun kemudian masa pertengahan adalah masa pergeseran dari bil ma"tsūr ke tafsir bil $r a^{\prime} y i^{23}$

Jika melihat Tafsir Ibn KatsDr walaupun masuk kedalam era pertengahan, dimana era ini tafsir bil ra'yi sudah sedikit mendominasi ${ }^{24}$, akan tetapi tafsir Ibn Kats $\square$ r kecenderungannya lebih

${ }^{22}$ Nasharuddin Baidan, Metode Penafsiran al-Qur'an "Kajian Kritis terhadap Ayat-ayat yang Beredaksi Mirip”, (Yogyakarta: Pustaka Pelajar, 2011), 57.

${ }^{23}$ Lihat, Abdul Mustaqim, Dinamika Sejarah tafsir al-Qur'an., 90.

${ }^{24}$ Dominasi tafsir Tafsir Bil Ra'yi pada era pertengahan lebih dikarenakan kondisi perpolitikan pada waktu itu, Khalifah al-Makmun pada masa itu menetapkan aliran Mu'tazilah sebagai mazhab Negara. Tentunya dengan kepuitusan itu berimplikasi pada model-model penafsiran. Seperti yang telah diketahui bahwa 
menggunakan bentuk tafsir bil ma'tsūr, menurut Adz-Zahabi Tafsir Ibn kats $\square$, menggunakan metode menafsirkan al-Qur' 'nn dengan alQur' $7 n$, menafsirkan al-Qur' $\square n$ dengan hadis, menafsirkan al-Qur' $\square n$ dengan melihat ijitihad-ijtihad para sahabat dan tabi'in ${ }^{25}$, menurut Ibn Kats $\square$ r dalam muqaddimah tafsirnya menyebut bahwa metode tersebut adalah metode yang terbaik dalam penafsiran al-Qur'an. ${ }^{26}$ Metode menafsirkan al-Qur' 'n dengan al-Qur' '-n, al-Qur' 'Dn dengan hadis dan seterusnya adalah merupakan prinsip-prinsip yang dipakai pada bentuk tafsir bil ma'tsur. Walupun sebenarnya tidak menutup kemungkinan ada bentuk-bentuk bil ra'yi dalam penafsirannya, sebagai contoh penakwilannya tentang ayat antropomorphisme di atas menunjukkan bahwa Ibn Kats $\square \mathrm{r}$ juag menggunakan $r a^{\prime} y u$ dalam penafsirannya. Akan tetapi dengan melihat tafsirannya secara keseluruhan, bentuk bil ma'tsūr lebih mendominasi. Hal itu dibuktikan banyaknya hadis-hadis yang digunakan oleh Ibn Kats $\square \mathrm{r}$ dalam penafsirannya. Hal ini bisa jadi, dikarenakan bahwa Ibn Kats $\square r$ adalah seorang yang pakar dibidang hadis (dan diberi gelar sebagai muhaddis).

\section{Metode Tafsir}

Metode tafsir adalah berkaitan dengan model penyajian. Nasaruddin Baidan membagi metode tafsir dalam empat bagian yaitu metode global (Manhaj Ijmāli) ${ }^{27}$, Metode Analitis (Manhaj Tahlīli ${ }^{28}$, Metode Tematik (Manhaj Mawdhu'i) ${ }^{29}$, dan Metode

Mu'tazilah lebih mengedepankan akal dalam penafsirannya. Oleh Karen itu pada era ini lebih didominasi bentuk tasfsir bil ra'yi. Lihat, Abdul Mustaqim, Dinamika Sejarah tafsir al-Qur'an., 97.

${ }^{25}$ Mani' Abd Halim Mahmud, Manhā $j$ al-Mufassirīn terj. Syahdianor dan Faisal Saleh, (Jakarta: Raja Grafindo Persada, 2003), 60.

${ }^{26}$ Abu al-Fida' Isma'il Ibn Umar Ibn Katsir al-Quraisy al Dimasyqy, Tafsīr al-Qur'ān al-Adzìm terj. Salim Bahreisy dan Said Bahreisy (ttp: tp,), xvi.

${ }^{27}$ Metode Ijmali at au global adalah metode yang digunakan oleh para mufassir dalam menafsirkan ayat-ayat al-Qur'an dengan penjelasan secara global. Metode ini hanya menggambarkan makna secara literal (literal meaning). Lihat, Samsul Bahri dkk, Metodologi Studi Tafsir, (Yogyakarta: Teras, 2010), 45.

${ }^{28}$ Metode analitis atau metode tahlili adalah metode yang menjelaskan kandungan al-Qur'an secara keseluruhan. Dan seorang penafsir menafsirkan alQur'an secara runtut dari awal hingga akhir sesuai dengan mushaf usmani. Lihat, Samsul Bahri dkk, Metodologi Studi Tafsir., 42.

${ }^{29}$ Metode Maudhu'I atau metode tematik adalah metode yang digunakan 
Komparatif (Manhaj Muqāran) ${ }^{30}$. Dalam penyajian tafsir Ibn Kats $\square$ r ini, menggunakan metode analitis (tahlili). Ibn Kats $\square$ r dalam tafsirnya menyajikannya secara runtut mulai dari surat al-Fatihah, al-Baqarah sampai al-Nas sesuai dengan mushaf Usmani. Dengan tidak mengabaikan aspek asbāb al-nuzūl dan juga munasabat ayat atau melihat hubungan ayat-ayat al-Qur' $\mathrm{nn}$ antara satu sama lain. ${ }^{31}$ Namun demikian, metode penafsiran kitab ini juga bisa dikatakan semi tematik ${ }^{32}$, karena dalam pembahasannya mengelompokkan ayatayat (sesuai urutan ayat) yang dianggap memiliki keterkaitan, kadang dua ayat, kadang tiga ayat dan kadang pula empat ayat. Sebagai contoh surat al-Baqarah ayat 120-121

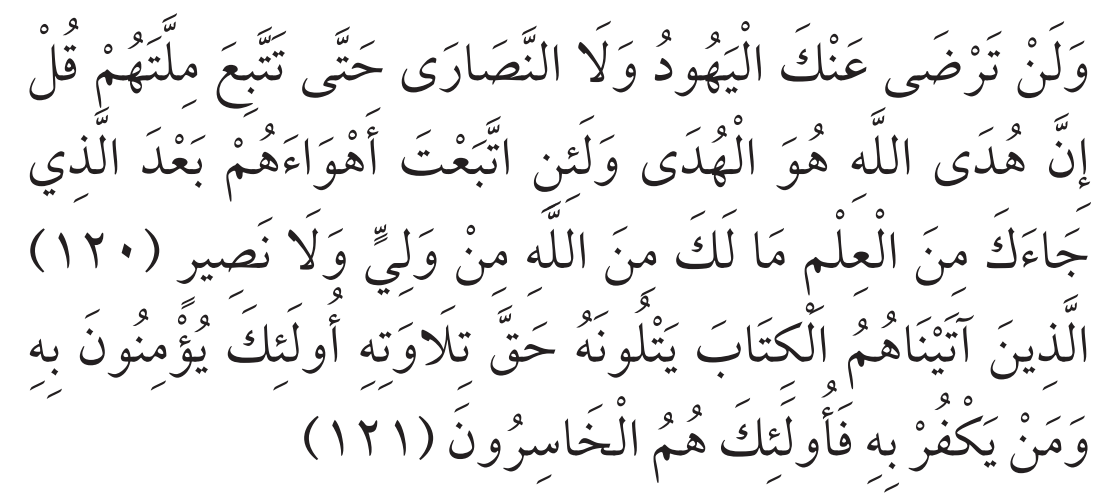

Terejemahnya: orang-orang Yahudi dan Nasrani tidak akan senang kepada kamu hingga kamu mengikuti agama mereka. Katakanlah: "Sesungguhnya petunjuk Allah Itulah petunjuk (yang benar)». dan Sesungguhnya jika kamu mengikuti kemauan mereka setelah pengetahuan datang kepadamu, Maka Allah tidak lagi menjadi pelindung dan penolong bagimu. orangorang yang telah Kami berikan Al kitab kepadanya, mereka membacanya dengan bacaan yang sebenarnya, mereka itu

untuk menjelaskan kandungan ayat-ayat al-Qur'an berdasarkan tema-tema tertentu di dalam al-Qur' an. Metode ini termasuk metode yang paling banyak digunakan di era kontemporer. Lihat, Samsul Bahri dkk, Metodologi Studi Tafsir., 47.

${ }^{30}$ Metode Muqaran ataumetode komparasi. Yaitumetode dengan menghimpun ayat-ayat al-Qur' an kemudian mengkajinya dengan melihat pandangan-pandangan dari para mufassair sekaligus menjelaskan kecenderungan para mufassir tersebut. Lihat, Samsul Bahri dkk, Metodologi Studi Tafsir., 46.

${ }^{31}$ Samsul Bahri dkk, Metodologi Studi Tafsir., 42.

${ }^{32}$ Dedi Nurhaedi dkk, Studi Kitab Tafsir, 138. 
beriman kepadanya. dan Barangsiapa yang ingkar kepadanya, Maka mereka Itulah orang-orang yang rugi.

Kedua ayat tersebut disatukan karena memilki keterkaitan antara ayat satu dengan ayat yang lainnya.

\section{Israiliyat dalam Tafsīr Ibn Katsīr}

Salah satu sumber penafsiran pada masa klasik/pertengahan adalah banyak kisah-kisah israiliyat yang disusupkan ke dalam tafsir maupun hadis. Kisah-kisah israiliyat adalah cerita-cerita kuno dari yahudi maupun nasrani atau pengaruh kebudayaannya terhadap tafsir. Cerita Israiliyat juga memilki jalur periwayatan, oleh karena itu ada israiliyat yang shahih dan ada yang dha'if, ada yang sesuai dengan syari'at islam dan ada yang tidak sesuai.

Walaupun Ibn Kats $\square r$ dikenal sebagai ahli hadis yang sangat selektif memilih riwayat-riwayat yang shahih, hal itu tidak menutup kemungkinan bahwa semua riwayat israiliyat yang dikemukakannya memiliki sanad yang shahih. Akan tetapi, ketika ia mengutip kisahkisah israiliyat yang dha'if, Ibn kats $\square r$ juga menjelaskan letak kedho'ifannya, atau ketika riwayatnya shohih ia juga menjelaskan keshahihannya Misalnya ketika Ibnu Katsir menfasirkan surat alNDzi'" t ayat 30: "dan bumi sesudah itu dihamparkan". Ibnu Katsir mengemukakan israiliyat yang disampaikan muslim dan dari Abu hurairah bahwasanya: "Allah telah menciptakan tanah pada hari sabtu, gunung pada hari ahad, pohon-pohon pada hari senin, sesuatu yang dibenci pada hari selasa, cahaya pada hari rabu, binatang pada hari kamis dan Adam pada hai Jum'at antara ashar dan malam.". menurut Ibn KatsDr, kisah ini sanadnya Gharib. Ada juga kisah yang dikemukakan oleh Ibn Kats $\square$, yang riwayatnya bersumber dari Ibnu Abbas, yang berbunyi: di balik bumi ini. Allah menciptakan sebuah lautan yang melingkupinya. Di dasar laut itu, Allah telah menciptakan pula sebuah gunung yang bernama Qaf. Langit dan buni ditegakkan di atasnya. Di bawahnya, Allah menciptakan langit yang mirip seperti bumi ini yang jumlahnya tujuh lapis. Kemudian di langit kedua ini ditegakkan di atasnya. Sehingga jumlah semuanya : tujuh lapis bumi, tujuh lautan, tujuh gunung, dan tujuh lapis langit". Israiliyat ini dikemukakan oleh Ibnu karsir untuk menjelaskan awal Surat Qaf. 
Menurutnya sanadnya terputus dan beretntangan dengan riwayat Ibnu Abbas lainnya. ${ }^{33}$ Ini berarti bahwa kisah-kisah israiliyat yang dho'if dalam tafsir Ibn Kats $\square$ r bukan merupakan tafsiran terhadap ayat, melainkan sebatas mengungkapkan bahwa dalam konteks ayat it u terdapat kisah-kisah israiliyat yang tidak boleh diberpegangi. Ibn katsロr juga memiliki pandanagan tentang israiliyat bahwa karena kisah-kisah israiliyat tidak diketahu kebenaran dan kebohongannya , maka berita itu tidak perlu dibenarkan sebab dimungkinkan mengandung dusta tetapi juga jangan didustakan sebab dimungkinkan masih mengandung kebenaran. ${ }^{34}$ Tercatat dalam tafsir Ibn Kats $\square \mathrm{r}$ terdapat 48 kisah israiliyat.

\section{Kesimpulan}

Sebagai kesimpulan dari pemaparan di atas, bahwa tafsir Ibn Kats $\square$ r muncul atau masuk dalam abad pertengahan (abad ke-8 H/ abad ke-15 M), akan tetapi jika dilihat dari sisi metode dan bentuk tafsir nya. Ibn Kats $\square$ r berada dalam posisi "tengah-tengah", artinya dari sisi bentuk ia berada dalam posisi klasik karena menggunakan bentu tafsir bil ma'tsūr, sedangkan jika dilihat dari sisi metode Ibn Kats $\square \mathrm{r}$ berada di posisi era pertengahan dengan menggunakan metode tahlili, dimana metode ini belum dilakukan ketika era klasik.

${ }^{33}$ Rosihon Anwar, Melacak Unsur-unsur Israiliyat.,. 127.
${ }^{34}$ Rosihon Anwar, Melacak Unsur-unsur Israiliyat.. 139. 


\section{Daftar Pustaka}

M. Quraish Shihab, Kaidah Tafsir "Syarat, ketentuan, dan Aturan yang Patut anda ketahui dalam memahami ayat-ayat al-Qur'an. Ciputat: Lentera Hati, 2013

Rosihon Anwar, Melacak Unsur-unsur Israiliyat dalam Tafsir AthThobari dan Tafsir Ibnu Katsir, Bandung: Pustaka Setia, 1999

Dedi Nurhaedi dkk, Studi Kitab Tafsir, Yogyakarta: Teras, 2004

Saiful Amin Ghofur, Mozaik Mufassir al-Qur'an (dari Klasik Hingga Kontemporer), Yogyakarta: Kaukaba, 2013

Muhammad Husain Al-Zahabi, Tafsìr wal mufassirūn Juz 1, Kairo: Maktabah Wahbah, 2000

Abu al-Fida' Isma'il Ibn Umar Ibn Katsir al-Quraisy al Dimasyqy, Tafsìr al-Qur'ān al-Adzìm, (Dar al-Tayyibah: tt)

Abdul Mustaqim, Dinamika Sejarah tafsir al-Qur'an "Studi Aliranaliran Tafsir dari Periode Klasik, Pertengahan Hingga Modern-Kontemporer", Yogyakarta: Ponpes LSQ kerja sama Adab Press, 2012

Abdul Mustaqim, Epistemologi tafsir Kontemporer, Yogyakarta: LKIS, 20012

Harun Nasution, Teologi Islam Jakarta: UI Press, 2010

Nasharuddin Baidan, Metode Penafsiran al-Qur'an "Kajian Kritis terhadap Ayat-ayat yang Beredaksi Mirip”, Yogyakarta:Pustaka Pelajar, 2011

Mani' Abd Halim Mahmud, Manhā j al-Mufassirīn terj. Syahdianor dan Faisal Saleh, Jakarta: Raja Grafindo Persada, 2003

Abu al-Fida' Isma'il Ibn Umar Ibn Katsir al-Quraisy al Dimasyqy, Tafsìr al-Qur'ān al-Adzìm terj. Salim Bahreisy dan Said Bahreisy ttp: tp,

Samsul Bahri dkk, Metodologi Studi Tafsir, Yogyakarta: Teras, 2010 